\title{
The Effect of Leaders' Adoption of Task-Oriented or Relationship-Oriented Leadership Style on Leader-Member Exchange (LMX), In the Organizations That Are Active In Service Sector: A Research on Tourism Agencies
}

\author{
Nilüfer Rüzgar ${ }^{1}$ \\ ${ }^{1}$ School of Foreign Languages, Bursa Technical University, Bursa, Turkey \\ Correspondence: Nilüfer Rüzgar, School of Foreign Languages, Bursa Technical University, Turkey
}

Received: February 3, 2018

Accepted: April 9, 2018

Online Published: April 10, 2018

doi:10.5430/jbar.v7n1p50

URL: https://doi.org/10.5430/jbar.v7n1p50

\begin{abstract}
It is essential in all organizations to provide integration of human resources and the organization, in terms of organizational effectiveness. In organizations that are active in service sector, this integration is especially important because of the fact that the employees are in face-to-face relationship with the customers. In this sense, the extent of responsibility on managers/leaders, is really important. Managers/leaders in organizations can adopt a leadership style and behave as "Task (Work) Oriented" or "Employee (Relationship) Oriented". The style that is adopted by the leader, has a considerable effect on their relationship with employees.

Leader-member Exchange Theory (LMX) is the leading theory that scrutinizes endogeneity and exogeneity. LMX, codes human resources as inner-group and outer-group in the context of leader-member exchange. The leadership styles that are adopted by the managers, have great impact on the exchange among leaders and subordinates. Thus, the subordinates perceive their situation either inner-group members or outer-group members.

The purpose of this study, is to find out the effect of the leadership style that is adopted by the managers on Leader-Member Exchange (LMX). In this context, a survey method is applied to the tourism agencies that are active in Yalova, Turkey. The survey consists Fiedler's LPC (least preferred co-worker) measure, Leader-member Exchange measure and demographical questions. According to the results, there is no statistically significant effect of Task Oriented leadership style on Self Oriented dimension of LMX. On the other hand, it has been found that there is statistically significant effect of Relationship Oriented Leadership Style on Self Oriented dimension of LMX.
\end{abstract}

Keywords: leadership, leadership styles, leader-member exchange

\section{Introduction}

Organizations' primary aim is to stay alive in a competitive environment, which is constantly changing and developing. In order to stay alive and gain competitive advantage, intellectual capital should not be ignored. In this sense, in each organization a leader is needed in order to grasp the complex nature of humanbeing, and lead the employees to achieve the organizational goals by integrating them with the organization (Kanıür, 2009). The leader's traits and behaviour tendency affects the subordinates in the sense of achieving the organizaitonal goals. The leader's adoption of task-oriented or relationship-oriented style, also affects the mutual exchange and relationship between the leader and the subordinates. The theory that explains the interaction between the leaders and the subordinates is called "Leader-Member Exchange Theory" (LMX). LMX has also a great impact on organizational effectiveness (Wang, 2010).

Service, cannot be dimensioned physically. This is because of the fact that its being dynamic. In addition to this, service is based on numerious activities that are led by human behaviour. The employees are face-to-face with customers all the time. In this sense, it is considered really important for service sector employees to feel themselves as the members of either inner-group or outer-group, in the frame of LMX. When the employees feel that they are members of inner-group, the contribution that they make to the organization and the service that they provide for the customer enhances. On the other hand, when employees feel that they are members of outer-group, they contribute to the organization in a minimum level, provide low quality service for the customers and display low performance (Wayne, Shore, and Liden, 1997). 
From these points of view, the study titled "The Effect Of Leaders' Adoption Of Task-Oriented Or Relationship Oriented Leadership Style on Leader-Member Exchange in the Organizations That are Active in Service Sector: A Research on Tourism Agents" is prepared. There a number of studies in literature that research the effects of LMX in both production and service sectors. However, the number of studies on service sector that scrutinizes the effects of leadership styles on LMX, are limited. Therefore, in this study, this problem is tried to be solved. In the first section, the conceptual framework is tried to be explained in terms of task-oriented and relationship-oriented leadership styles. In the following section, LMX is tried to be explained with its components. In both sections, examples from previous researches on leadership styles and LMX are given. In the last section, the findings are evaluated and final discussion is prepared in accordance with both the findings and future researches.

\section{Task-Oriented Leadership}

Task-oriented leadership is a behavioral approach, in which the leader focuses on the tasks that need to be performed in order to meet certain goals, or to achieve a certain performance standard.

The task-oriented leadership style covers some features of task management. Task management, requires coordination of job-related activities, giving importance to administrative activities, supervising product quality and preparing financial reports. Thus, it can be concluded that the leaders who adopt task-oriented leadership style, focus on completing necessary tasks in order to reach organizational targets. One of the distinctive characteristics of these leaders, is that they are less concerned with the employees, who are actually the critical agents to achieve the desired goals. On the contrary, they are more concerned with following a planned path in order to achieve specific organizational targets (Forsyth and Donelson, 2010).

\subsection{Strengths of Task-Oriented Leadership}

One of the biggest strengths of task-oriented leadership is; all required jobs are completed perfectly and in a timely manner. This strength, ensures employees manage their time well. Furthermore, task-oriented leaders constitute an example for employees by focusing on the necessary workplace procedures, in the sense of how the duties are fulfilled. Thus they can delegate work and ensure that duties are completed in a timely and productive manner (Anzalone and Chris 2012).

As for the other strengths of task-oriented leadership style, the purpose is clear and the task definitions are precise. Leaders are open to communication in the sense that they want to be sure that the targets are clearly understood by the employees. In addition to this, they design work groups for specific tasks and ensure that group members have a clear understanding of their roles. Therefore, it can be concluded that this leadership style is suited to well-structured work environments, such as manufacturing assembly lines, in which repeating well-defined processes results in high levels of productivity and quality (Fiedler, 1964).

\subsection{Weaknesses of Task-Oriented Leadership}

As for the weaknesses of the task-oriented style, a fear of breaking the rules among employees, may result in a lack of creativity, low morale and thus, high turnover. When employees afraid to break rules, they may not take any risks, and therefore there may occur a lack of innovation. Moreover, the employees who are really creative, may feel demoralized and tend to leave their current organizations so as to find more appealing opportunities in other organizations (Bass, 1990).

Another weakness is seen in organizations which operate in highly competitive industries, such as retail or food services. These organizations must be able to immediately react to external threats and opportunities in order to survive. Therefore their employees should take risks, and this may make them not feel comfortable (www.mindtools.com).

\section{Relationship-Oriented Leadership}

Relationship-oriented leadership is an approach which focuses on the job satisfaction, motivation and work-life balance of the employees.

The leaders who adopt this style, are focused on supporting, motivating and developing their employees. They encourage teamwork and collaboration, by building positive relationships and encouraging communication. Relationship-oriented leaders prioritize the welfare of every single employee, and do not hesitate to spend time and effort in meeting their individual needs. In this sense, they offer incentives like bonuses, try to deal with workplace conflicts, have more casual interactions with employees to learn about their strengths and weaknesses and create a non-competitive work environment (Reilly and Anthony 1968). 


\subsection{Strengths Of Relationship-Oriented Leadership}

One of the strengths of this leadership style is that relationship-oriented leaders create teams that everyone wants to be a part of. Team members are often more productive and willing to take risks, because they know that the leader will provide support if they need it. Another strength of relationship-oriented leadership is that the employees are in an environment where their leader cares about their welfare.

These type of leaders are aware that productivity in the work place, requires building a positive environment where individuals feel motivated. Therefore these types of leaders prioritiz people to ensure that problems such as dissatisfaction, boredom, personal conflicts and turnover, stay at a minimum (Graen and Uhl-Bien, 1995).

With relationship-oriented leadership, leaders are totally focused on organizing, supporting, and contributing to the development the members in their teams. This is a participatory style and tends to encourage good teamwork and creative collaboration. In this sense, it is the opposite of task-oriented leadership. Furthermore, team members may be more willing to take risks, because they are aware of the fact that their leader will provide support whenever needed (Arana et. al., 2009).

\subsection{Weaknesses Of Relationship-Oriented Leadership}

One of the weaknesses of relationship-oriented leadership is; the development of team spirit may hinder completing the actual tasks and desired goals (Burke et. al., 2006).

Some leaders can take this approach too far; they may put the development of their team above tasks or project directives ( www.mindtools.com).

In addition, if employees have too much responsibility without leader guidance, the decision-making duty can become challenging and this may lead to lower performance, high employee turnover, customer dissatisfaction and decreased profitability (Tabernero et.al., 2009).

\section{The Fiedler Contingency Model}

The Fiedler Contingency Model puts forward three situational dimensions that determine whether task-oriented or relationship-oriented leadership is the best for the current situation of the organization (Fiedler, 1964):

1. Leader-Member Relations, referring to the degree of trust, respect and confidence between the leader and the subordinates.

2. Task Structure, referring to the extent which group tasks are clear and structured.

3. Leader Position Power, referring to the power inherent in the leader's position itself.

When there is a good leader-member relation, a highly structured task, and high leader position power, the situation is considered a "favorable situation" (Fiedler, 1964).

The table below shows the theory: Table 1: Fiedler, F. E. 1964. A Contingency Model of Leadership Effectiveness, Advances in Experimental Social Psychology, Volume 1, 1964, Pages 149-190.

Table 1. Contingency model of leadership effectiveness

\begin{tabular}{llll}
\hline $\begin{array}{l}\text { Leader-Member } \\
\text { Relations }\end{array}$ & Task Structure & Leader's Position Power & Most Effective Leader \\
\hline Good & Structured & Strong & Task-Oriented \\
Good & Structured & Weak & Task-Oriented \\
Good & Unstructured & Strong & Task-Oriented \\
Good & Unstructured & Weak & Relationship-Oriented \\
Poor & Structured & Strong & Relationship-Oriented \\
Poor & Structured & Weak & Relationship-Oriented \\
Poor & Unstructured & Strong & Relationship-Oriented \\
Poor & Unstructured & Weak & Task-Oriented \\
\hline $\begin{array}{l}\text { The table below } \\
\text { http://sourcesofinsight.com/when-to-use-task-oriented-vs-relationship-oriented-leadership-styles/ styles: Table }\end{array}$
\end{tabular}


Table 2. Task-oriented vs. relationship oriented leadership

\begin{tabular}{ll}
\hline Task-Oriented & Relationship-Oriented \\
\hline Emphasis on work facilitation & Emphasis on interaction facilitation \\
Focus on structure, roles and tasks & Focus on relationships, well-being and motivation \\
Produce desired results is a priority & Positive relationships is a priority \\
Emphasis on a clear plan to achieve goals & $\begin{array}{l}\text { Emphasis on team members and communication inside } \\
\text { the organization }\end{array}$
\end{tabular}

Strict use of schedules and step-by-step plans, and a Casual interactions and frequent team meetings punishment/incentive system

\section{Previous Research On Task-Oriented And Relationship-Oriented Leadership Styles}

There are various studies in literature that try to determine the effects of task-oriented and relationship-oriented leadership. While some of them show that relationship-oriented leadership produces greater productivity (Fiedler, 1964), some show that task-oriented leaders create greater productivity and effectiveness (Carron and Chelladurai 1983).

However, a common finding is that, relationship-oriented leadership provides a greater group cohesion, as well as a greater group learning (Johannsen, 2012). It is also stated in the researches that relationship-oriented leadership, has stronger individual impact, and a positive effect on self-efficacy.

For example, an experiment was conducted in 1972 by Chemers and Skrrzypek, with 128 United States Military cadets, in order to test the validity of Fiedler's contingency model in terms of leadership effectiveness. The experiment, which involved strong manipulation and specification of variables affecting situational favorableness, produced support for the mentioned model.

Another study by Carron and Chelladurai (1983) was conducted to determine if basketball athletes of different age groups preferred training and instruction (task-oriented) behavior or social support (relationship-oriented) behavior. Results showed that preference of task-oriented behavior progressively decreased among lower high school students, and increased among the university students. On the other hand, a linear trend was seen for preference in relationship-oriented behavior, which progressively increased as age went up.

\section{The Theory Of LMX and Main Approaches}

In this section, Leader-Member Exchange (LMX) is tried to be explained in the sense of organizational dynamics and as parallel to the leadership styles, which are mentioned in the previous section.

LMX theory, is considered as the most effective theory that investigates the relationship between leadership process and the results of this process (Özutku, Ağca and Cevrioğlu, 2007). LMX model, is a descriptive model instead of being a predictive model, which means that it doesn't try to explain the quality of leader-member relationships and the effectiveness of the leader. It, on the other hand, tries to describe the level of pre-LMX and the level of post LMX (Philips ve Bedeian, 1994). The approach that constitutes the base of LMX, is a dyadic approach that gives primary importance to the interpersonal relationships. LMX Theory, is about dyadic relationships and in such kind of relationships, the leaders do not take the differences among the subordinates into consideration (Brower, Schoorman and Tan, 2000). LMX Theory, suggests that there occur interpersonal relationships among the leaders and the subordinates, at the backstage of the formal relationships. It also suggests that there are some factors between these groups such as the exchange of material sources and the exchange of knowledge/information (Wayne, Shore and Liden, 1997).

LMX Theory, argues that the leader, contrary to the traditional approach which suggests that the leader approaches to the subordinates with the same leadership style, approaches to each subordinate with a different leadership style. According to this approach, the leader classifies the subordinates as "inner-group" or "outer-group". Low level of LMX, which implies a lack of trust and formal management system (Breland et. al., 2007), causes the subordinates feel themselves as the member of outer group. On the other hand, high level of LMX, which implies mutual trust, respect, love and mutual effect, causes the subordinates feel themselves as the member of inner group (Liden and Maslyn, 1998). In this sense, as the leader empowers the subordinates and approaches them with tolerance, the subordinates' perception of organizational commitment increases and they work harder with a greater performance (Bauer and Green, 1996). On the other hand, outer group members display a routine performance and do not receive much tolerance from the leader (Liden and Graen, 1980). While evaluating the performance of the outer group 
member; the leader gives minimum support, minimum trust and minimum rewards (Dinesh and Liden, 1986). As for the inner group members, the leader evaluates the subordinates more positively, with maximum trust, and devotes more time (Wayne, Shore and Liden, 1997). Dinesh and Liden (1986), mention that the characteristic traits of both the leader and the subordinate, affect the relationships between them. When the characteristic traits are same or similar, the mutual effect increases; thus, the trust that occurs mutually provides a permanent relationship.

\subsection{Theories And Approaches About LMX}

The primary theories that shape LMX, are "Role-Making Theory" and "Social Exchange Theory". In addition to these theories, "Human Capital Theory" and "Psychological Contract Theory" are two important theories that are evaluated in the literature in terms of LMX.

\subsubsection{Role-Making Theory}

Role-making theory, which is proposed by Graen and Scandura (1987), includes social exchange and attribution theories. Role-making, enhances the style and the quality of the relationship between the leader and the subordinates (Brower, Schoorman and Tan, 2000). The theoritical framework of LMX, is constituted with the help of role-making theory. According to this theory, the leaders examine their subordinates in terms of different work experiences. The extent of the harmony between the subordinates' experiences and their demands about work and along with their merits, identifies the accuracy of LMX relationship styles. The style of LMX, which is defined by the subordinates' exchange in their work behavior, causes leader to respond with organizational sources such as information, change of positions and autonomy (Liden and Maslyn, 1998).

\subsubsection{Social Exchange Theory}

"Social Exchange Theory", is proposed by Blau (1964). According to the theory, social exchanges necessitates undefined obligations. When a person does a kindness to another person, he/she feels pretty sure that he/she will get a respond in an undefined time, place and style in the future (Wayne, Shore and Liden, 1997).

\subsubsection{Psychological Contract Theory}

Psychological contract theory, is used when it is necessary to explain the relationships, which cannot be defined properly, between the leader and the subordinates. The perceptions of the subordinates constitute the base of this theory. The theory is defined by Rousseau as the personal belief of a promise that will come true in the future and liability of future advantages. Although it is considered as individual, it is evaluated as a contract that includes mutual liabilities of the leader and the subordinate (Philips and Bedeian).

\subsubsection{Human Capital Theory}

All of the information and knowledge that contributes to the creativity of the subordinate and that is obtained by inner feelings of outer factors, are defined as human capital. Factors such as the capability of observation, work experience and life experience; make great contributions to the employee and provide the chance of evaluating both the co-employees and the organization in a holistic point of view (Akdemir, 2013).

\subsection{Previous Research on LMX}

There are numerious researches in literature on LMX in terms of role taking, performance, satisfaction, turnover and career development (Breland et. al., 2007).

As an example, Liden and Graen (1980)'s research proves that the subordinates who have high quality relationships with their leaders, make greater contribution to the organization and show better performance when compared to the subordinates who have low quality relationship with their leaders.

Liang, Ling and Hsieh (2007) conducted a research in Taiwan, which is a famous country for its communitarian culture, with 215 military leaders and 430 subordinates. They found that, LMX acts as an agent in the relationship between the leader's helpful and autocratic behaviour and organizational citizenship.

In another research which is carried by Duarte et. al. (1994), it is found that the quality of the leader-member exchange has relationship with the time that is spent together with the leader and the subordinate, which contributes to the performance of the subordinate.

Dyne and Ang (1998), Gilder (2003), Nashwall (2003) examined the effect of subordinates' having a temporary or permanent contract on inner-group and outer-group membership. It is surprising that the subordinates who have temporary contract have higher inner-group status perception than the subordinates who have permanent contract, because of the fact that they build positive relationships with both the leaders and the co-workers (Lapalme et. al. , 2009). 


\section{Methodology}

\subsection{Purpose and Scope}

The purpose of this study, is to investigate the effects of the adopted leadership styles by leaders, on LMX. In this sense, tourism agents that are active in Yalova are evaluated as the main population. The surveys are distributed via hardcopies and via e-mail and 96 individuals participated the survey. The statistical analyses are applied via SPSS 20.0 package programme.

\subsection{Hypotheses}

The hypotheses are as follow:

H0: There is not a statistically significant effect of task-oriented leadership on LMX.

H1: There is a statistically significant effect of task-oriented leadership on LMX.

H0: There is not a statistically significant effect of relationship-oriented leadership on LMX.

$\mathrm{H} 2$ : There is a statistically significant effect of relationship-oriented leadership on LMX.

\subsection{Measures}

In this study, the data is collected via surveys. The measures that are used in surveys are Fiedler's Least Preferred Co-Worker Scale, which has 18 items and aims to find out the leadership style of the leader as task oriented or employee oriented, by the leader's evaluation of the least preferred co-worker; and Liden and Maslyn's Leader-Member Exchange Scale, which has 12 items. The reliability statistics of the scales are measured as acceptable. There are also demographical questions that aim to collect personal information such as age, gender, marital status and work experience.

\section{Findings}

According to the factor analysis of LMX scale (Table 3), the items are gathered under 3 dimensions/components. These dimensions are labeled as "Member-Oriented", "Leader-Oriented" and "Self-Oriented".

Table 3. Leadership Style Scale Factor Analysis

\begin{tabular}{lccc}
\hline & \multicolumn{3}{c}{ Component } \\
\cline { 2 - 4 } & 1 & 2 & 3 \\
\hline LeadershipStyle11 &, 948 & & \\
LeadershipStyle7 &, 874 & & \\
LeadershipStyle9 &, 864 & & \\
LeadershipStyle8 &, 698 & & \\
LeadershipStyle6 &, 612 &, 798 & \\
LeadershipStyle3 & &, 797 &, 630 \\
LeadershipStyle2 & & &, 764 \\
LeadershipStyle5 & & &, 743 \\
LeadershipStyle3 & & & \\
LeadershipStyle4 & & & \\
LeadershipStyle15 & & &
\end{tabular}

According to the factor analysis of Leadership Styles scale (Table 4), the items are gathered under 2 dimensions. These dimensions are labeled as "Relationship-Oriented" and "Task-Oriented". 
Table 4. Leader-Member Exchange Scale Factor Analysis

\begin{tabular}{|c|c|c|}
\hline \multicolumn{3}{|c|}{ Component } \\
\hline & 1 & 2 \\
\hline LMX8 & \multicolumn{2}{|l|}{,941 } \\
\hline LMX10 & \multicolumn{2}{|l|}{, 915} \\
\hline LMX2 & \multicolumn{2}{|l|}{, 843} \\
\hline LMX6 & \multicolumn{2}{|l|}{, 817} \\
\hline LMX1 & \multicolumn{2}{|l|}{,693 } \\
\hline LMX4 & \multicolumn{2}{|l|}{,632 } \\
\hline LMX3 & \multicolumn{2}{|l|}{,601 } \\
\hline \multicolumn{3}{|l|}{ LMX9 } \\
\hline LMX7 & &, 854 \\
\hline LMX11 & & ,829 \\
\hline LMX12 & & 811 \\
\hline \multirow[t]{2}{*}{ LMX5 } & & 807 \\
\hline & &, 783 \\
\hline \multicolumn{3}{|c|}{$\begin{array}{l}\text { According to the regression analysis (Tables } 5 \text { and 6), there is no statistically significant effect of leadership styles } \\
\text { on Leader Oriented and Member Oriented dimensions of LMX. Thus, hypotheses } 1 \text { and } 2 \text { are partially rejected. } \\
\text { Table 5. Anova }\end{array}$} \\
\hline
\end{tabular}

\begin{tabular}{|c|c|c|c|c|c|c|}
\hline \multirow[b]{3}{*}{ Phase } & & \multicolumn{2}{|c|}{$\begin{array}{l}\text { Unstandardized } \\
\text { Coefficients }\end{array}$} & \multirow[t]{2}{*}{$\begin{array}{l}\text { Standardized } \\
\text { Coefficients }\end{array}$} & \multirow[b]{3}{*}{$\mathrm{t}$} & \multirow[b]{3}{*}{$\mathrm{p}$} \\
\hline & & \multirow[b]{2}{*}{ B } & Standard & & & \\
\hline & & & Error & Beta & & \\
\hline \multirow[t]{3}{*}{1} & (Leader-Oriented) & 14,418 & 2,281 & & 6,321 & ,000 \\
\hline & Relationship-Oriented &,- 111 &, 120 &,- 107 &,- 921 & ,359 \\
\hline & Task-Oriented &, 060 &, 163 &, 042 &, 365 & ,716 \\
\hline
\end{tabular}

\begin{tabular}{|c|c|c|c|c|c|c|}
\hline \multirow[b]{3}{*}{ Phase } & & \multicolumn{2}{|c|}{$\begin{array}{l}\text { Unstandardized } \\
\text { Coefficients }\end{array}$} & \multirow[t]{2}{*}{$\begin{array}{l}\text { Standardized } \\
\text { Coefficients }\end{array}$} & \multirow[b]{3}{*}{$\mathrm{t}$} & \multirow[b]{3}{*}{$\mathrm{p}$} \\
\hline & & \multirow[b]{2}{*}{ B } & Standard & & & \\
\hline & & & Error & Beta & & \\
\hline \multirow[t]{3}{*}{1} & (Member-Oriented) & 21,288 & 3,228 & & 6,596 & ,000 \\
\hline & Relationship-Oriented &,- 072 &, 170 &,- 049 &,- 423 & ,673 \\
\hline & Task-Oriented & ,067 &, 231 & ,034 & ,292 &, 771 \\
\hline
\end{tabular}

According to the regression analysis (Table 7), there is no statistically significant effect of Task Oriented Leadership Style on Self Oriented dimension of LMX. On the other hand, it has been found that there is statistically significant effect of Relationship Oriented Leadership Style on Self Oriented dimension of LMX. When the adoption of Relationship Oriented Leadership Style increases, the employees increase their behaviour in developing themselves individually. Thus, hypothesis 1 is partially accepted. 
Table 7. Anova

\begin{tabular}{|c|c|c|c|c|c|c|}
\hline \multirow[b]{3}{*}{ Phase } & & \multicolumn{2}{|c|}{$\begin{array}{l}\text { Unstandardized } \\
\text { Coefficients }\end{array}$} & \multirow[t]{2}{*}{$\begin{array}{l}\text { Standardized } \\
\text { Coefficients }\end{array}$} & \multirow[b]{3}{*}{$\mathrm{t}$} & \multirow[b]{3}{*}{$\mathrm{p}$} \\
\hline & & \multirow[b]{2}{*}{ B } & Standard & & & \\
\hline & & & Error & Beta & & \\
\hline \multirow[t]{3}{*}{1} & (Self-Oriented) & 6,378 & 3,066 & & 2,080 & ,040 \\
\hline & Relationship-Oriented & ,830 & ,161 & ,498 & 5,146 & ,000 \\
\hline & Task-Oriented & 261 & ,219 & ,115 & 1,188 & 238 \\
\hline
\end{tabular}

\section{Conclusion and Discussion}

Leadership, which enhances HR, has a strong effect in terms of relationship. Leaders' being task-oriented or employee-oriented, influences the subordinates and they are classified as inner-group or outer-group members by their leaders.

Effective managers/leaders are aware of the time that they should use the task-oriented leadershipstyle and/or relationship-oriented leadership style. For example, in the relationship-oriented style, managers aim at providing welfare of their employees and provide a motivating environment to maximize their productivity. Thus, they enhance the quality of leader-member relationship. On the other hand, managers can use the task-oriented leadership style to define tasks and expectations, which can sometimes cause leader-member relationship to become low.

According to the findings of this study, there is no statistically significant effect of Task Oriented leadership style on Self Oriented dimension of LMX. On the other hand, it has been found that there is statistically significant effect of Relationship Oriented Leadership Style on Self Oriented dimension of LMX. Thus, it can be concluded that leaders should try to scrutinize the effects of each leadership style thoroughly so as to make their employees work more beneficially and productively. In addition to this, both the leadership styles and LMX theory should be comprehended by both the leaders and the employees, so that each individual in the organization, whether they are managers/leaders or subordinates, will put effort into developing themselves individually as well as developing the organization in a holistic way.

The population of the study, which was tourism agencies in Yalova, is a limitation in the sense that it is difficult to generalize the results to the whole region or the whole country. Therefore, for future studies there should be more researches on service sector in other cities. In addition to this, it is also necessary to conduct researches on production sector as well so as to compare and contrast the results and contribute to the literature.

\section{References}

Akdemir, A. (2013). Stratejik Yönetim. T.C. Anadolu Üniversitesi Yayını, No. 2681, Açıköğretim Fakültesi Yayını No. 1647.

Anzalone, C. (2012). Differences between task-oriented leaders and relational-oriented leaders. Demand Media.

Arana, J. M.; Chambel, M. J., Curral, L. \& Tabernero, C. (2009). The role of task-oriented versus relationship-oriented leadership on normative contract and group performance. Social Behavior and Personality: an international journal. 37 (10).

Aslan, Ş. \& Özata M. (2011). Lider-üye etkileşiminin (LMX) yöneticiye duyulan güven düzeyine etkisi. SÜ İIBF Sosyal ve Ekonomik Araştırmalar Dergisi.

Bass, B.M. (1990). Bass \& Stogdill's handbook of leadership: Theory, research, and managerial applications (3rd ed.). New York, NY: Free Press.

Bauer, T. N. \& Green, S. G. (1996). Development of leader-member exchange: A longitudinal test. Academy of Management Journal, 39(6), 1538-1567. https://doi.org/10.2307/257068

Breland, J. W., Treadway, D. C., Duke, A. B. \& Adams, G. L. (2007). The interactive effect of leader-member exchange and political skill on subjective carrier success. Journal of Leadership \& Organizational Studies, 13 (3), 1-14. https://doi.org/10.1177/10717919070130030101

Brower, H. H., Schoorman, F. D. \& Tan, H. H. (2000). A model of relational leadership: The integration of trust and 
leader-member exchange. Leadership Quarterly, $11 \quad$ 227-250. https://doi.org/10.1016/S1048-9843(00)00040-0

Burke, C. S., Stagl, K. C., Klein, C., Goodwin, G. F., Salas, E. \& Halpin, S. M. (2006). What type of leadership behaviors are functional in teams? A meta-analysis. The Leadership Quarterly, (17), 288-307. https://doi.org/10.1016/j.leaqua.2006.02.007

Carron, A. V. \& Chelladurai, P. (1983). Athletic maturity and preferred leadership. Journal of Sport Psychology, 5 (4), 371-380. https://doi.org/10.1123/jsp.5.4.371

Chemers, M. M. \& Skrzypek, G. J. (1972). Experimental test of the contingency model of leadership effectiveness. Journal of Personality and Social Psychology, 24 (2), 172-177. https://doi.org/10.1037/h0033371

Duarte, N. T., Goodson, J. R. \& Klich, N. R. (1994). Effects of dyadic quality and duration on performance appraisal. Academy of Management Journal, 37(3), 499-521. https://doi.org/10.2307/256698

Fiedler, F. E. (1964). A contingency model of leadership effectiveness. Advances in Experimental Social Psychology. 1 (1), 149-190. https://doi.org/10.1016/S0065-2601(08)60051-9

Forsyth, D. R. (2010). Group dynamics. (5th ed.). Belmont, CA: Wadsworth Cengage Learning.

Gilder, D. (2003). Commitment, trust and work behaviour: The case of contingent workers. Personnel Review, 32(5), 588-604. https://doi.org/10.1108/00483480310488351

Graen, G. B. \& Uhl-Bien, M. (1995). Relationship-based approach to leadership: Development of leader-member exchange (LMX) theory of leadership over 25 years: Applying a multi-level multi-domain perspective. Management Department Faculty Publications. Paper 57. https://doi.org/10.1016/1048-9843(95)90036-5

Johannsen, M. (2012). The importance of choosing the right leadership style. Legacee.

Liang, S.-K., Ling, H.-C. \& Hsieh, S.-Y. (2007). The mediating effects of leader-member exchange quality to influence the relationships between paternalistic leadership and organizational citizenship behaviors. Journal of American Academy of Business, 10(2), 127- 137.

Liden, R. C. \& Maslyn, J. M. (1998). Multidimensionality of leader-member exchange: An empirical assessment through scale development. Journal of Management, 24(1), 43-72.

Liden, R. \& Graen, G.B. (1980). Generalizability of the vertical dyad linkage model of leadership. Academy of Management Journal, 23, 451-465. https://doi.org/10.2307/255511

Mayer, R.C., Davis, J.H., \& Schoorman, D. (1995). An integrative model of organizational trust. Academy Of Management Review, 20, 709-734.

Özutku, H., Ağca, V. \& Cevrioğlu, E. (2007). Lider-üye etkileşim teorisi çerçevesinde, yönetici-ast etkileşimi ile örgütsel bağlılık boyutları ve iş performansı arasındaki ilişki: Ampirik bir inceleme. XV. Ulusal Yönetim ve Organizasyon Kongresi, Sakarya Üniversitesi, 25-27 Mayıs 2007, Sakarya.

Phillips, A. S. \& Bedeian, A. G.. (1994). Leader-follower exchange quality: The role of personal and interpersonal attributes. Academy of Management Journal, 37(4), 990-1001. https://doi.org/10.2307/256608

Reilly, A. J. (1968). The effects of different leadership styles on group performance: A field experiment. Retrospective Theses and Dissertations. Paper 3510.

Shore, L. M. (2010). Inclusion and diversity in work groups: A review and model for future research. Journal of Management, 1-28.

Tabernero, C., Chambel, M. J., Curral, L. \& Arana, J. M. (2009). The role of task-oriented versus relationship-oriented leadership on normative contract and group performance. Social Behavior and Personality: An International Journal, 37(10), 1391-1404(14).

Uhl-Bien, M. (2006). Relational leadership theory: Exploring the social processes of leadership and organizing. The Leadership Quarterly, 17, 654-676. https://doi.org/10.1016/j.leaqua.2006.10.007

Wang, L. (2010). Leader-member exchange and organizational citizenship behavior: A new perspective from perceived insider status and chinese traditionality. Frontiers Business Research China, 4(1), 148-169. https://doi.org/10.1007/s11782-010-0007-1

Wayne, S. J., Shore, L. M. and Liden, R. C. (1997). perceived organizational support and leader-member exchange: A social exchange perspective. The Academy of Management Journal, 40(1), 82-111. 
https://doi.org/10.2307/257021

http://www.mindtools.com/pages/article/leader-member-exchange.htm

www.smallbusiness.chron.com

http://sourcesofinsight.com/when-to-use-task-oriented-vs-relationship-oriented-leadership-styles/

"The Blake Mouton Managerial Grid". Mind Tools. Retrieved 2 November 2012.

\section{Appendix 1. LMX Scale}

\begin{tabular}{|c|c|c|c|c|c|c|}
\hline & $\begin{array}{l}\text { Leader-Member Exchange } \\
\text { Level }\end{array}$ & $\begin{array}{l}\text { Strongly } \\
\text { Disagree }\end{array}$ & Disagree & Not Sure & Agree & $\begin{array}{l}\text { Strongly } \\
\text { Disagree }\end{array}$ \\
\hline 1 & I like my leader as a human & & & & & \\
\hline 2 & $\begin{array}{l}\text { My leader, defends me against } \\
\text { my other superordinates }\end{array}$ & & & & & \\
\hline 3 & $\begin{array}{l}\text { I complete tasks just form y } \\
\text { leader, although they are not } \\
\text { my responsibility }\end{array}$ & & & & & \\
\hline 4 & $\begin{array}{l}\text { My leader's knowledge about } \\
\text { the job, impresses me }\end{array}$ & & & & & \\
\hline 5 & $\begin{array}{l}\text { My leader is like a friend for } \\
\text { me }\end{array}$ & & & & & \\
\hline 6 & $\begin{array}{l}\text { My leader defends me against } \\
\text { my co-works in case of a } \\
\text { verbal attack }\end{array}$ & & & & & \\
\hline 7 & $\begin{array}{l}\text { I work overtime voluntarily so } \\
\text { as to help my leader }\end{array}$ & & & & & \\
\hline 8 & $\begin{array}{l}\text { I respect my leader's } \\
\text { knowledge and capability } \\
\text { about the work }\end{array}$ & & & & & \\
\hline 9 & $\begin{array}{l}\text { It is a pleasure for me to work } \\
\text { with my leader }\end{array}$ & & & & & \\
\hline 10 & $\begin{array}{l}\text { If I make a mistake } \\
\text { unintentionally, my leader } \\
\text { defends me against my } \\
\text { co-workers and superordinates }\end{array}$ & & & & & \\
\hline 11 & $\begin{array}{l}\text { I adore my leader's expertise } \\
\text { skills }\end{array}$ & & & & & \\
\hline 12 & $\begin{array}{l}\text { For my leader, I never hesitate } \\
\text { completing even the most } \\
\text { difficult tasks }\end{array}$ & & & & & \\
\hline
\end{tabular}




\section{Appendix 2. Least Preferred Co-Worker Scale}

\begin{tabular}{lll}
\hline & & \\
\hline Pleasing & 87654321 & Unbearable \\
Friendly & 87654321 & Unfriendly \\
Objector & 12345678 & Receptor \\
Understandable & 87654321 & Complicated \\
Tense & 12345678 & Calm \\
Distant & 12345678 & Close \\
Remote & 12345678 & Sincere \\
Boring & 12345678 & Interesting \\
Aggressive & 12345678 & Coherent \\
Pessimist & 12345678 & Cheerful \\
Honest & 87654321 & Dishonest \\
Dedikoducu & 12345678 & Loyal \\
Unreliable & 12345678 & Reliable \\
Inactive & 12345678 & Active \\
Polite & 87654321 & Rude \\
Colloborative & 87654321 & Uncolloborative \\
Coşkusuz & 12345678 & Enthusiastic \\
Bad & 12345678 & Good \\
& & TOTAL POINTS \\
\hline
\end{tabular}

